\title{
Andreas Schulz* \\ "What does it have to do with us?" - Rethinking the Russian Revolution in Germany
}

\section{IZVLEČEK}

\section{»KAJ IMA TO OPRAVITI Z NAMI?« - PONOVNO VREDNOTENJE RUSKE REVOLUCIJE V NEMČIJI}

Avtor predstavlja pregled razstav in novejših publikacij v Nemčiji, posvečenih stoti obletnici oktobrske revolucije leta 1917. Po stoletju raziskovanja sta veličastnost in herojstvo iz časov rojstva »velike socialistične oktobrske revolucije« že povsem zbledela. $Z$ demistifikacijo se je tako imenovana »svetovna revolucija « premaknila $v$ okvir ruske zgodovine. Vendar ta nacionalizacija revolucije marginalizira globalne posledice Rdečega oktobra, zlasti kadar se boljševiški prevzem oblasti razlaga preprosto kot uspešno prizadevanje za preoblikovanje anarhije $v$ organizirani režim terorja, ki ga je izvajala odločna in požrtvovalna avantgarda. Medtem ko totalitarni pristop zanemarja socialne korenine revolucije, novejše kulturne študije poudarjajo naključne dejavnike in degradirajo revolucionarno vstajo kot eskalacijo državljanske vojne na kontaminiranih »območjih nasilja«. Avtor v drugem delu tega prispevka pusti za sabo vse takšne celovite razlage in velike načrte ter opozori na dolgotrajne strukturne spremembe, $k i$ jih je ruska revolucija povzročila v povojni Evropi. Svoje argumente osredotoči na tri ravni - najprej na politične institucije, nato na gospodarski in družbeni red, nazadnje pa na demografske spremembe.

Ključne besede: čaščenje spomina na »svetovno revolucijo «, globalne posledice leta 1917, vplivi Rdečega oktobra na Nemčijo 


\section{ABSTRACT}

The author reviews exhibitions and recent publications in Germany which commemorate the centennial of the October Revolution 1917. After a full century of research there is little left of glory and heroism that had been present at the dawn of the "Great Socialist October Revolution". A de-mystification has taken place which relocates the proclaimed "World Revolution" into the frame of Russian history. But this nationalization of the revolution tends to marginalize the global effects of the Red October, especially when the Bolshevik seizure of power is simply explained as a successful effort to transform anarchy into an organised regime of terror practised by a determined and self-sacrificing Avantgarde. While the totalitarian approach neglects the social origins of the Revolution, recent cultural studies emphasise contingent factors downrating revolutionary uprisings as an escalation of civil war in contaminated "landscapes of violence". Leaving behind such entire explanations and grand designs, the second part of this paper wants to draw attention to the enduring structural changes which the Russian Revolution caused in post-war Europe. The author concentrates his arguments on three levels, beginning with the political institutions, secondly, the economic and social order, and thirdly, the demographic change.

Keywords: Commemorating the "World Revolution", Global effects of 1917, Impacts of the Red October on Germany

In the calendar of centennial commemorations of the October Revolution in Germany, the exhibition "1917 Revolution - Russland und die Folgen" in the Deutsche Historische Museum in Berlin had a prominent place. "What does the revolution have to do with us?" - is a rhetorical question, which the curators did not specifically answer because they were more interested in the celebrations of the revolutionary heritage in post-soviet Russia. ${ }^{1}$ But indeed, looking back from 2017, it is evident that nothing is left of the hopes and fears that contemporaries all over the world shared when the Bolsheviks announced the dawn of a new age of mankind under the name of the "Great Socialist October Revolution". ${ }^{2}$ With the end of the Cold War, it seemed as if the global revolutionary challenge and the utopian promises, which the Soviet Union held up as the legitimate heir of Leninism, completely disappeared. ${ }^{3} \mathrm{~A}$ brief look at the bestseller book list shows that the year 1917 has become a rather forgotten time in history. While the commemoration of the "Great War" from 1914 to 1918

1 Kristiane Janeke, "Einführung," in: 1917. Revolution: Russland und die Folgen (Berlin: Sandstein Verlag, 2017), 1013.

2 Eric J. Hobsbawm, Das Zeitalter der Extreme: Weltgeschichte des 20. Jahrhunderts 1914-1991 (München: Hanser, 1995), 91-93.

3 Jan Claas Behrends et. al., "100 Jahre Roter Oktober. Versuche zur Historisierung der Russischen Revolution," in: 100 Jahre Roter Oktober. Zur Weltgeschichte der Russian Revolution (Berlin: Christoph Links, 2017), 9. Jan C. Behrends, "Was bleibt vom Kommunismus? Eine historische Betrachtung zum 100. Jahrestag der Russischen Revolution," in: 1917. 100 Jahre Oktoberrevolution und ihre Fernwirkungen auf Deutschland (Baden-Baden: Nomos, 2017), 23-37. 
produced a rich harvest of detailed studies ${ }^{4}$, which claim to deliver new insights, recent publications about the Russian Revolution of 1917 remain in the shadow of latest historiographical research. Nonetheless, it is worth considering its significant importance once again after a hundred years, despite the fact that the "World Revolution”, which Lenin and the Bolsheviks proclaimed, never happened.

\section{A Final Farewell to the World Revolution?}

A full century of research has de-mystified the Russian Revolution, leaving little of the glory and heroism which had always surrounded memories and historiography. ${ }^{5}$ Some historians wonder if the revolution really mattered enough to call it a break of continuity in contemporary world history at all. There is a growing tendency to locate the years 1917-1920 in the frame of Russian history, so that we may speak of a "de-globalisation" and "nationalisation" of the October Revolution. How this rearrangement has changed our general perception of the Russian Revolution will be discussed in the first part of this paper. It is evident that with the end of the Cold War, ideological debates ceased and grand narratives fell silent. However, there is reason enough to consider the immediate impacts and long-term structural changes that the revolution caused. This will be explored in the second part of this paper.

\section{Relocating the Russian Revolution}

It has long been common knowledge that the Russian Revolution was a turning point in world history because it laid the foundations for a global bi-polar division between liberal-capitalist "Western" democracies and the socialist hemisphere, dominated by a Soviet system and based on social collectivism and state economy. Historians in the GDR periodically celebrated the Bolshevik Revolution as the beginning of an age of emancipation which liberated mankind from expropriation and imperialistic wars. Their "bourgeois" counterparts in West Germany agreed with them insofar as they recognised the global historical dimension of the revolution. In the aftermath of the dissolution of the Soviet Union, this perception entirely changed. Only a marginalised group of convinced Marxist-Leninists remains engaged in periodical commemorations of the "Great Socialist October Revolution", thus preserving the canonical interpretation of the Bolsheviks' historical mission. ${ }^{6}$ With

4 Books on First World War are bestsellers, see for example: Jörn Leonhard, Die Büchse der Pandora. Geschichte des Ersten Weltkriegs (München: C.H.Beck, $\left.{ }^{5} 2014\right)$. Herfried Münkler, Der große Krieg. Die Welt 1914-1918 (Berlin: Rowohlt, ${ }^{4} 2014$ ).

5 Gerd Koenen, "Der 'Rote Oktober' als Mythos und Utopicum," in: Russland und die Folgen, 141-57.

6 See for example the contributions to the 10th conference of Historical Research organised by the "Marxistische Arbeitskreis zur Geschichte der deutschen Arbeiterbewegung bei der Historischen Kommission der Partei des Demokratischen Sozialismus (PDS)" in 1997: Lothar Berthold, "Sie war und bleibt die Große Sozialistische Oktoberrevolution!'," in: Die Oktoberrevolution 1917 und ihr Platz in der Geschichte (Bonn: Pahl-Rugenstein, 1997), 
the vanishing aurora of the "Red October", the main stream of research is re-directing its orientation, substituting the outlook on the global impacts of the revolution with a retrospection on its national origins. Historians are turning their attention to the late Empire, explaining the Russian Revolutions in view of the economic crises and social uprisings which accelerated the breakdown of the Empire. ${ }^{8}$ The great narratives published in Germany during the last few years tell us about Russian history, thereby emphasising the singularity of the Russian revolutions from February to October 1917. However, nationalising the October Revolution does not necessarily imply neglecting or denying its considerable impacts on other countries, which will be demonstrated later in the paper. It is not a complete revision but rather a de-mystification of the glorious "Great Socialist Revolution" that has taken place, returning Red October back into Russian history.

\section{Revolutionary Leviathan}

Marxist historiography has failed to validate its "scientific" dogma of the inevitability of a socialist world revolution terminating the age of capitalism. Treating history as a continuous progression of mankind towards perfection, made the October Revolution appear inevitable. Quite a corresponding teleology is offered by Western theories of modernisation, which presume a final destination of modern civil societies. According to each country's current level of participation, industrialisation and pluralism, standards of "advanced democracies" are developed, dividing the world into areas of progression and regression. In reference to this paradigm of progress, the Russian Revolutions were qualified as "crises", resulting from the disability of an autocratic state to adjust its traditional society and local economy to global modernisation.

Anticipations concerning the irreversibility of the emancipation of mankind, the progress of democracy and economic globalisation did affect historiographic research on the Russian Revolution for quite some time. Obviously, the progressive approach to history tended to emphasise the structural deficiencies of the autocratic system in the late Empire. Unlike the dynasty's violent physical elimination, the Empire of the Romanovs suffered a silent breakdown rather than being swept away by revolutionary force. The "failed" Empire did not simply drown in anarchy and civil war, contrary to what the liberal opponents of the Russian revolutionaries have always maintained. Against all expectations, the Bolshevik Revolution finally succeeded in establishing a centralised bureaucratic party-rule. It continued to submit civil society to the

71-81. Stefan Doernberg, "Oktoberrevolution - Epochenwechsel oder Weg in die Sackgasse?," in: Die Oktoberrevolution 1917 und ihr Platz in der Geschichte, 9-26. Martin Sabrow, "Der 'Rote Oktober' und sein Nachhall im geteilten Deutschland," in: Russland und die Folgen, 125-39.

7 François Furet, Das Ende der Illusion. Der Kommunismus im 20. Jahrhundert (München and Zürich: Piper, $\left.{ }^{2} 1996\right)$ 87-137, 549-97. Behrends et. al., Historisierung, 26.

8 Manfred Hildermeyer, Geschichte Russlands vom Mittelalter bis zur Oktoberrevolution (München: C.H.Beck, 2013). Manfred Hildermeyer, Die Sowjetunion 1917-1991 (Berlin: De Gruyter, ${ }^{32016) . ~ H e l m u t ~ A l t r i c h t e r, ~ R u s s l a n d ~} 1917$. Ein Land auf der Suche nach sich selbst (Paderborn: Ferdinand Schöningh, ${ }^{2} 2017$ ). 
restructured state authority. Converting the former imperial military and police forces to loyal instruments, the Bolshevik Leviathan practised (red) terror in similar ways to how the autocratic monarchy had exerted power. ${ }^{9}$

Recent historiography evidently adopts a renewed totalitarianism-paradigm, explaining that the seizure of power and the regime of total control, that the Bolshevik intelligentsia established, was for their own sake. After the victorious pacification of the Civil War, the mission of authoritarian rule and state monopolism was accomplished. ${ }^{10}$ Its centralised state power and modernism was pushed forward by a determined elite, who acted with revolutionary energy. The analogy of this narrative to Tocqueville's "Ancien Régime and the Revolution" and the liberal interpretation of the French Revolution is obvious. ${ }^{11}$ Aside from this "statist" view, there is a growing inclination to avoid such all-embracing "entire" explanations. Recent research has taken into account the peculiarities, singularities and contingencies of Russian history which might not be derived from general assumptions about authoritarian pre-dispositions of a centralised state. The outstanding personality of Lenin, the self-sacrificing ideological determination of the revolutionary "Avantgarde", and the massive agrarian discontent might be mentioned as crucial elements of an exceptional case of revolutionary pre-conditions. ${ }^{12}$

\section{Extinguishing Revolutionary Time - The Continuous Experience of War and Violence}

Not surprisingly, the cultural turn produced some essential revisions in historiography which might be considered as a marginalisation of the October Revolution. Historians representing the current main-stream of "culturalism" have dismissed the breaking-point of 1917 in the continuum of a history of violence linking Imperial Russia, the October Revolution and the Civil War. ${ }^{13}$ A landscape of "killing fields" and "areas of violence" ("Gewalträume") is constructed, where everyone is exposed to an overwhelming experience of destruction, lawlessness and murder. Deprived

9 See chapter II "Ein Staat in der Krise," in: Altrichter, Russland 1917, 192-259. Resuming latest research: Hildermeyer, Sowjetunion. For a differentiating and critical Marxist interpretation see: Helmut Bock, "Die Russische Revolution 1917-1921 - Sieg oder Tragödie?," Pankower Vorträge, No. 71 (2005).

10 Martin Malia, Vollstreckter Wahn. Russland 1917-1991 (Stuttgart: Klett-Cotta, 1994). Hildermeyer, Sowjetunion, 117-22.

11 Arno J. Mayer, The Furies. Violence and Terror in the French and the Russian Revolution (Princeton/NJ: Princeton University Press, 2000).

12 Bock, Russische Revolution, 29-46.

13 Jörg Baberowski and Gabriele Metzler, eds. Gewalträume - soziale Ordnungen im Ausnahmezustand (Frankfurt am Main: Campus Verlag, 2012). Jörg Baberowski, Räume der Gewalt (Frankfurt am Main: S. Fischer, ${ }^{2} 2015$ ). Dietrich Beyrau, Krieg und Revolution. Russische Erfahrungen (Paderborn: Ferdinand Schöningh, 2017), 200-26. Felix Schnell, Räume des Schreckens. Gewalträume und Gruppenmilitanz in der Ukraine 1905-1933 (Hamburg: Hamburger Edition, 2012). Peter Holquist, Making War, Forging Revolution. Russia's Continuum of Crisis, 1914-1921 (Cambridge/Mass.: Harvard University Press, 2002). Anna Greifman, Thou Shalt Kill. Revolutionary Terrorism in Russia, 1894-1917 (Princeton/NJ: Princeton University Press, 1993). 
of the ability to establish civil order, people submit to the iron circle of violence and counter-violence, thereby losing control of themselves and becoming active participants of crime. Criminals and victims merge in a "timeless" slaughter, in an "orgy of destruction" ${ }^{14}$ where terror and revenge, banditry and looting, hooliganism and alcoholism, ethnic fighting, pogroms and deportations eliminate social order until state authority finally collapses. Amidst this apocalyptic battlefield, the Bolsheviks advance to the stage, presenting themselves as the only players who are determined to re-establish order by force of violence. ${ }^{15}$

In this perspective, the Russian Revolution and Civil War merely appear as an escalation of violence, and the Bolshevik seizure of power as a successful effort to transform anarchy into an organised regime of "Red Terror". Did Leninism conceptualise party rule and social control as self-serving, creating nothing else but a revolutionary culture of force and order? Recent cultural studies pay attention to the popular claim for terminating war and pacifying civil conflicts which the Bolshevik's political agenda supported. Nevertheless, a historiographic creation of "landscapes of violence" obviously neglects social incentives for popular uprisings in Russia. Grand designs of revolution and war history tend to disconnect the time and place of the Revolution of 1917, illustrating Red October as either a collective effort to terminate fighting or as a revolutionary coup d'état which established an organised terror regime in a contaminated area where violence and killing is an elementary "timeless" experience. ${ }^{16}$

The de-mystification and nationalisation of Red October has drawn attention away from the reverberations that the Russian Revolution released far beyond its borders, especially in the belligerent countries of the First World War. The immediate impacts of the revolution and the enduring structural changes it caused in post-war Europe will be discussed in the second part of this paper.

\section{Impacts of the Russian Revolution in Europe: the German and the British Case}

Immediate reactions all throughout Europe occurred when the news of the February Revolution spread. In war-sick Germany, hopes of reaching a separate peace agreement with Russia grew, and the massive intervention of the Entente powers during the Civil War provoked solidarity with the Bolsheviks, especially among workers. The British suffragist Emmeline Pankhurst, who had travelled on a 4-month journey to

14 Jörg Baberowski, "Die Russische Revolution und die Neuordnung der Welt," in: 1917 Revolution - Russland und die Folgen, 21.

15 Beyrau, Krieg und Revolution, 207.

16 Jörg Baberowski, "Verwüstetes Land: Macht und Gewalt in der frühen Sowjetunion," in: Gewalträume, 169-89. A more differentiated study is: Stefan Plaggenborg, Revolutionskultur. Menschenbilder und kulturelle Praxis in Sowjetrussland zwischen Oktoberrevolution und Stalinismus (Köln et al.: Böhlau, 1996). Stefan Plaggenborg, Ordnungen der Gewalt: Sozialismus, Kemalismus, Faschismus (München: Oldenbourg Wissenschaftsverlag, 2012). 
Revolutionary Russia to urge the Provisional Government to carry on the war against the Mittelmächte on the Eastern front, had initially welcomed the February Revolution as a step towards parliamentary democracy. When she returned home in October 1917, she warned that a political seizure of power by the Bolsheviks was near. They would take Russia out of the war and then conclude a separate peace with Germany.

While Pankhurst was performing her patriotic mission in Petrograd, the German secretary of the International League of Women, Clara Zetkin, had concluded her break from the Social Democratic party which had been her home from the beginning of her political life. The revolutions in Russia turned Zetkin's misery into excited expectations of a decisive turnover of world history. Recovering from a period of depression and loneliness caused by her disillusion about the failure of workers internationalism against imperialistic war, Zetkin was literally reborn as a communist activist, preparing herself for the prospective venue of the forthcoming World Revolution. In a message to the Komintern (Communist International), she declared her devotion to "socialist Soviet Russia", celebrating the October Revolution as "the mighty sun, rising in crimson splendor out of the darkness and horror of the World War". ${ }^{17}$ One of the signatures on an international address of solidarity, which she directed to the Bolsheviks in November 1919, was written by Sylvia Pankhurst who had openly diverted from the political course of her mother, Emmeline.

The reflections on the revolutions in Russia from two outstanding political women could not have been more conflicting. Whereas Emmeline Pankhurst had turned away from her radical origins, Zetkin embraced the Red Revolution as the dawn of a liberated mankind. Apart from their personal involvement, their reactions also reflect the different impacts that the revolutions in Russia had on the belligerent nations in the First World War. While the victorious Entente countries soon returned to parliamentary government, the monarchies of the Central powers were swept away by revolutionary uprisings. However, all efforts to light a revolutionary fire failed, and the slogan "Proletarier aller Länder, vereinigt euch!" (Proletarians of all countries, unite!), which was first addressed to German workers, was met with weak support among the Spartacus League and the Internationalists.

Although expectations of a coming World Revolution were soon disappointed, people would not lose hope for a better future in post-war Europe. Some parts of the political Left observed the Russian experience following the October Revolution. Promises that the Bolsheviks made concerning social reform, land re-distribution, popular education and women's emancipation supported the European workers movement's essential claims. Russia and the Soviet-Union remained a point of reference for labour force, and an incentive and challenge for European democracies. While recent German historiography commemorates the Revolution in Russia, after

17 " $[$... die große gewaltige Sonne, die in purpurner Pracht aus dem Dunkel und Grauen des Weltkriegs emporsteigt"; quoted in: Tânia Puschnerat, Clara Zetkin - Bürgerlichkeit und Marxismus. Eine Biografie (Essen: Klartext Verlag, 2003), $222 \mathrm{f}$. 
100 years, there is reason enough to re-consider the long-term effects it might have had on the Weimar Republic's liberal democracy.

The year 1917 was a turning point for the constitutional monarchies in Germany and Austria. When the Social Democratic Party refused to give further approval to war loans, this signalled the end of the national war consensus which the Emperor had proclaimed in August 1914. An informal political coalition of the "Parliamentary Left", which included the catholic Zentrumspartei, Left Liberals and Social Democrats, agreed on a resolution in the Reichstag, announcing to the world that Germany should declare its will to conclude a peace without annexations and reparations. The famous Reichstag Peace Resolution of July 1917 openly referred to the Petrograd Soviet which had proclaimed a fundamental rupture with the conventional logic of fighting and waging war earlier in the year. When the German Supreme Command ignored the parliamentarian majority's initiative by submitting Russia to a dictatorial Peace Treaty and intensified its useless war efforts, the Germany public lost faith in the military and political leadership of the monarchy. News about the Revolution in Russia aggravated the growing discontent in Germany, but it can hardly be claimed that the constant loss of popular loyalty was due to the propaganda war that the Bolsheviks staged against imperialism. It was not the suspected "stab-in-the-back" (Dolchstoss) led by revolutionary elements of a treacherous "Homefront", but rather the failed Siegfriedenstrategy which caused the collapse of the monarchies. Therefore, if we want to reflect the impacts of the Russian Revolution, we have to go beyond the political turnover of the German November Revolution in 1918 and consider the long-term effects. My paper concentrates on three levels, beginning with political institutions, secondly, the economic and social order, and thirdly, the demographic change.

1. The complete failure of the military and political leadership's war strategy made constitutional reforms, including the enfranchisement of the bulk of the working population, indispensable. However, the sudden turn over of the 1918 October cabinet to a republican order came too late. Mutinies in the army, as well as in major factories, had already broken out, leading directly to the German November Revolution. Spontaneous, grass-roots councils of soldiers and workers were spreading all over the country. They directly referred to the Russian soviets, such as the Workers and Soldiers Council of the Free City of Hamburg which proclaimed that "Soviet Russia and the Soviets of Hamburg are inseparably connected". ${ }^{18}$ Even in England, where labour movement and trade unions had ceased their strike activities in 1914, a Council of Workmen of more than a thousand representatives gathered in the Coliseum of the industrial city of Leeds, which was known as The Leeds Soviet. It warmly hailed the Russian Revolution and called upon the establishment of "Councils of Workmen and Soldiers" in every town, urban and

18 "... ] das revolutionäre Hamburg hat durch die Tat bewiesen, dass das Russland der Räteregierung und die Räteregierung Hamburgs eine Einheit sind, die nichts trennen kann", in: Hamburger Echo, 7 November 1918, quoted in: Volker Stalmann and Jutta Stehling, Der Hamburger Arbeiter- und Soldatenrat 1918/19 (Düsseldorf: Droste, 2013), 43. 
rural district. They regarded the Russian Soviets as a historical achievement of the working class which would one day become the nucleus of a new social order in Britain. Similar conventions in Newcastle and Manchester were soon suppressed by police force under the provisions of the Defense of the Realm Act. ${ }^{19}$ Although their hope of launching a British network of extra-parliamentarian Soviets with sovereign powers failed, workers felt encouraged by their Russian comrades to enforce their bargaining power. They were politicised by watching the Russian revolutionary experience.

But whereas the British version of Soviets remained a marginal phenomenon that did not cause much attention in historiography, there was a lengthy debate in Germany during the 1970s about the reform potential of the Rätebewegung (Council Movement). Evidence proved that most of the revolutionary delegates themselves did not claim to represent a political alternative to parliamentary democracy, but rather a means of political control to secure the transfer of power to the parties of the working class. Apart from this, people did not believe that the Russian experience would survive much longer, and even the radical Left rejected "bolshevist terror" ${ }^{20}$ However, one should not underestimate the Rätebewegung's commitment and solidarity with the Russian soviets which they perceived as a strong symbol of the Revolution, showing that the working class was prepared to seize power and establish a participatory model of workers democracy. ${ }^{21}$ Indeed, the independent Rätebewegung practised a transfer of revolutionary experience from Russia to Germany, and when the elected representatives of German workers referred to the Russian Soviets, they were demonstrating their solidarity with them. Yet, revolutionary internationalism soon faded away when the soviets were subordinated to the "iron discipline" of the centralised Bolshevik partyrule. Whereas the soviets became virtually powerless, the Betriebsräte (Work Council) in Germany survived as an instrument of participatory democracy in industrial working relations. The so-called "Paritätische Mitbestimmung" (Equal Participation) remains, to this day, a basic institutional pillar of the Social Market Economy of the Federal Republic.

2. Although the origins of the national welfare state go back to the last quarter of the $19^{\text {th }}$ century, there can be no doubt about the importance of social legislation following the First World War. Total war meant heavy casualties, broken lives and financial losses for most families at home. War victims had to be compensated for enduring sacrifices. The obligation to care for the masses of war veterans, disabled

19 Northern Voices: The Leeds Soviet - 1917!, 15 February 2018, http://northernvoicesmag.blogspot.de/2017/01/ the-leeds-soviet-1917.html. Ian Bullock, Romancing the revolution: the myth of Soviet democracy and the British Left (Edmonton: Athabasca University Press, 2011), 41-88.

20 Heinrich Laufenberg (1872-1937) former member of the Social Democrats (SPD), 1919 member of the Communist Party (KPD), first President of the Hamburg Workers and Soldiers Council until 21/1/1919, quoted in: Stalmann and Stehling, Der Hamburger Arbeiter- und Soldatenrat 1918/19.

21 David Priestland, "The Left and the Revolutions," in: The Oxford Handbook of European History, 1914-1945 (Oxford: Oxford University Press, 2016), 88-91. 
people, widows and orphans, refugees and displaced personsled to a vast extension of state allowances, pensions and other sources of material relief. Social Security was thus, essentially, a material compensation for the war commitment of European populations. Nevertheless, the strong demand for social improvements has to be interpreted in close relation to the rising force of working class movements all across Europe. Strike activities returned in 1917 after the patriotic war consensus in the belligerent nations ended, also affecting neutral countries such as Spain. The Bolshevik government in Russia indicated the power of the labour force, increasing trade unionism and industrial unrest, even in remote England, where some leading members of the Labour Party "felt disquiet about "the potential for a revolutionary situation"”. ${ }^{22}$ Obviously, British parliamentary government was discredited since it couldn't solve the Irish Question, nor conclude peace with its enemies of war. Political polarisation divided the country and split the women's liberation movement from which Sylvia Pankhurst and her radical comrades turned away in order to join the Communist International in 1919. She called for a peace settlement and dreamed of a "Socialist Commonwealth", whereas her mother Emmeline patriotically continued to support the war efforts of the British Government.

It is evident that when industrial strikes targeted the capitalist economy, their agenda was at least partly influenced by the Russian Revolution. The Soviet State proclaimed a fundamental reverse of labour relations, setting free peasants and industrial workers as a political force. ${ }^{23}$ Factory workers' self-governing committees, the centralisation of distribution and the promise of a socialist producers' community that would replace market relations offered an alternative model of a non-capitalist political economy. The Russian experience thus remained a source of permanent incentives and challenges for Western capitalism, which forced post-war governments to improve social relations at home. Corporatism and organised capitalism in England or Weimar Germany could therefore be seen as a reaction to Soviet "State Capitalism", bringing forth preventive Social Welfare legislation, destined to discipline and integrate the labour force.

3. War and revolution caused an unprecedented population transfer, especially in Eastern and South-Eastern Europe. The decomposition of the Habsburg, Ottoman and Romanov Empires led to a massive demographic drain of expatriates, creating new ethnic urban quarters in those countries which took them in. Ethnic cleansing had its origins in the war when national minorities were suspected as enemies who posed a threat to the national political community. The Civil War in Russia motivated the beleaguered Soviet government to dislocate greater parts of its native population which it suspected as being politically unreliable. Political pressure exerted on minorities released a second wave of mass migration which 
followed the millions of people fleeing from war and violence inside the territory of Imperial Russia - a whole empire walking, to use the famous phrase from Peter Gatrell. ${ }^{24}$ The bulk of refugees were expropriated and expatriated individuals and families, now "stateless", former residents of aristocratic or bourgeois origin and also ethnic minorities that were forced to seek shelter elsewhere. When these groups targeted European capitals such as Constantinople, Paris, Prague, Belgrade or Berlin, they experienced new hardships laid upon them by authorities who perceived them as strangers or even hostile groups who threatened the social homogeneity of the indigenous community.

The Russian Revolution challenged the world with the "first modern refugeecrisis". ${ }^{25}$ Stateless émigrés from Russia either had to rely on the acceptance of the Nansen-passport by foreign countries, or address single refugee relief organisations supported by the League of Nations. Immigrants arriving in Weimar-Germany were treated in different ways according to administrative categories referring to their supposed ethnic origins or social status, such as the Jewish refugees from Russia, Latvia or Poland who were merged into a single ethnic category labelled "Ostjuden". ${ }^{26}$ This East-Jewish minority population remained an object of popular disdain, whereas the Russian community in Weimar-Germany, which numbered about half a million people at its peak at the beginning of the 1920s, succeeded to establish enduring cultural and social structures. Although Russian refugees were dispersed soon after living conditions deteriorated in late Weimar Germany and moved on westwards, they left the memory of Russki Berlin behind them which remains, even today, an essential part of the history of Berlin, for example "Charlottengrad" amongst other places.

What does the Russian Revolution have to do with us? Reviewing the present state of research, it might seem as if the revolution was closely linked to war and the crisis of Imperial Russia. The vast literature on the World War has emphasised the contingent factors of military events and, at the same time, neglected social forces and political power structures in the belligerent societies. Finally, Red October appears merely as a secondary act in the grand drama of the European theatre of war. ${ }^{27}$ Much has been written about "blood lands" and "killing fields" in certain contaminated areas, where violence has been a constant experience of everyday life since the beginning of the $20^{\text {th }}$ century. Culturalist liberal historians tend to pay more attention to mental and cultural dispositions, which they consider to be relevant, to explain popular uprisings.

24 Peter A. Gatrell, A Whole Empire Walking. Refugees in Russia During World War I (Bloomington/Indiana: Indiana University Press, 1999).

25 Behrends et. al., Historisierung, 14. Catherine Gousseff, L'exile russe. La fabrique du réfugié apatride (1920-1939) (Paris: CNRS Éditions, 2008).

26 Heiko Haumann, Geschichte der Ostjuden (München: DTV, '62008 [1990]), 77-89, 190-96. Frank M. Schuster, Zwischen allen Fronten. Osteuropäische Juden während des Ersten Weltkrieges (1914-1919) (Köln et al.: Böhlau, 2004).

27 Münkler, Der Große Krieg, 546-58, 617-18, 653-56, is rating the decay of the Imperial Army and the violent military suppression of social uprisings in Petrograd much higher than the social origins of the Revolution. 
However, a globalising approach which lacks to investigate specific constellations which caused revolutions in Russia, Germany, Hungary, or elsewhere risks downrating them as secondary phenomena to the Great War or as just another stage in an ongoing rage of civil war which turned the heart of Europe into a united slaughterhouse. What we tried to do here instead was to consider the different settings of political and social conditions that separated European countries during the war and which made them more or less susceptible to the challenges of the Russian Revolutions. Differentiations and comparisons are necessary to help us understand why the "Great Socialist October Revolution" is still relevant after 100 years.

\section{Sources and Literature}

- Altrichter, Helmut. Russland 1917. Ein Land auf der Suche nach sich selbst. Paderborn: Ferdinand Schöningh, ${ }^{2} 2017$ (1997).

- Baberowski, Jörg and Gabriele Metzler, eds. Gewalträume - soziale Ordnungen im Ausnahmezustand. Frankfurt am Main: Campus Verlag, 2012.

- Baberowski, Jörg. "Die Russische Revolution und die Neuordnung der Welt." In: 1917. Revolution: Russland und die Folgen, eds. Deutsches Historisches Museum and Schweizer Nationalmuseum, 15-26. Berlin: Sandstein Verlag, 2017.

- Baberowski, Jörg. Räume der Gewalt. Frankfurt am Main: S. Fischer, ${ }^{2} 2015$.

- Baberowski, Jörg. "Verwüstetes Land: Macht und Gewalt in der frühen Sowjetunion." In: Gewalträume, eds. Jörg Baberowski and Gabriele Metzler, 169-89. Frankfurt am Main: Campus Verlag, 2012.

- Behrends, Jan C., Nikolaus Katzer and Thomas Lindenberger. "100 Jahre Roter Oktober. Versuche zur Historisierung der Russischen Revolution." In: 100 Jahre Roter Oktober. Zur Weltgeschichte der Russian Revolution, eds. Jan C. Behrends, Nikolaus Katzer and Thomas Lindenberger, 9. Berlin: Christoph Links, 2017.

- Behrends, Jan C. "Was bleibt vom Kommunismus? Eine historische Betrachtung zum 100. Jahrestag der Russischen Revolution." In: 1917. 100 Jahre Oktoberrevolution und ihre Fernwirkungen auf Deutschland, eds. Tilman Mayer and Julia Reuschenbach, 23-37. Baden-Baden: Nomos, 2017.

- Berthold, Lothar. "'Sie war und bleibt die Große Sozialistische Oktoberrevolution!'." In: Die Oktoberrevolution 1917 und ihr Platz in der Geschichte, ed. Marx-Engels-Stiftung, 71-81. Bonn: Pahl-Rugenstein, 1997.

- Beyrau, Dietrich. Krieg und Revolution. Russische Erfahrungen. Paderborn: Ferdinand Schöningh, 2017.

- Bock, Helmut. "Die Russische Revolution 1917-1921 - Sieg oder Tragödie?." Pankower Vorträge, No. 71 (2005).

- Bullock, Ian. Romancing the revolution: the myth of Soviet democracy and the British Left. Edmonton: Athabasca University Press, 2011.

- Doernberg, Stefan. “Oktoberrevolution - Epochenwechsel oder Weg in die Sackgasse?.” In: Die Oktoberrevolution 1917 und ihr Platz in der Geschichte, ed. Marx-Engels-Stiftung, 9-26. Bonn: PahlRugenstein, 1997.

- Furet, François. Das Ende der Illusion. Der Kommunismus im 20. Jahrhundert. München and Zürich: Piper, ${ }^{2} 1996$ [Le passé d'une illusion. Essai sur l'idée communiste au XXe siècle, Paris: R. Laffont/ Calmann-Léyy, 1995].

- Gatrell, Peter A. A Whole Empire Walking. Refugees in Russia During World War I. Bloomington/ Indiana: Indiana University Press, 1999. 
- Gousseff, Catherine. L'exile russe. La fabrique du réfugié apatride (1920-1939). Paris: CNRS Éditions, 2008.

- Greifman, Anna. Thou Shalt Kill. Revolutionary Terrorism in Russia, 1894-1917. Princeton/NJ: Princeton University Press 1993.

- Haumann, Heiko. Geschichte der Ostjuden. München: DTV, ${ }^{6} 2008$ (1990).

- Hildermeyer, Manfred. Die Sowjetunion 1917-1991. Berlin: De Gruyter, ${ }^{3} 2016$.

- Hildermeyer, Manfred. Geschichte Russlands vom Mittelalter bis zur Oktoberrevolution. München: C.H.Beck, 2013.

- Hobsbawm, Eric J. Das Zeitalter der Extreme: Weltgeschichte des 20. Jahrhunderts 1914-1991. München: Hanser, 1995 [The Age of Extremes: A History of the World, 1914-1991. New York: Vintage Books, 1996].

- Holquist, Peter. Making War, Forging Revolution. Russia's Continuum of Crisis, 1914-1921. Cambridge/Mass.: Harvard University Press, 2002.

- Janeke, Kristiane. "Einführung." In: 1917. Revolution: Russland und die Folgen, eds. Deutsches Historisches Museum and Schweizer Nationalmuseum, 10-13. Berlin: Sandstein Verlag 2017.

- Koenen, Gerd. "Der 'Rote Oktober' als Mythos und Utopicum." In: 1917. Revolution: Russland und die Folgen, eds. Deutsches Historisches Museum and Schweizer Nationalmuseum, 141-57. Berlin: Sandstein Verlag, 2017.

- Leonhard, Jörn. Die Büchse der Pandora. Geschichte des Ersten Weltkriegs. München: C.H.Beck, ${ }^{5} 2014$.

- Malia, Martin. Vollstreckter Wahn. Russland 1917-1991. Stuttgart: Klett-Cotta, 1994.

- Mayer, Arno J. The Furies. Violence and Terror in the French and the Russian Revolution. Princeton/ NJ: Princeton University Press, 2000.

- Münkler, Herfried. Der Große Krieg. Die Welt 1914-1918. Berlin: Rowohlt, ${ }^{7} 2014$.

- Northern Voices: The Leeds Soviet - 1917!. 15 February 2018. http://northernvoicesmag.blogspot. de/2017/01/the-leeds-soviet-1917.html.

- Plaggenborg, Stefan. Ordnungen der Gewalt: Sozialismus, Kemalismus, Faschismus. München: Oldenbourg Wissenschaftsverlag, 2012.

- Plaggenborg, Stefan. Revolutionskultur. Menschenbilder und kulturelle Praxis in Sowjetrussland zwischen Oktoberrevolution und Stalinismus. Köln et al.: Böhlau, 1996.

- Priestland, David. "The Left and the Revolutions." In: The Oxford Handbook of European History, ed. Nicholas Doumanis, 88-91. Oxford: Oxford University Press, 2016.

- Purvis, June. Emmeline Pankhurst - a Biography. London: Routledge, 2002.

- Puschnerat, Tânia. Clara Zetkin - Bürgerlichkeit und Marxismus. Eine Biografie. Essen: Klartext Verlag, 2003.

- Sabrow, Martin. "Der 'Rote Oktober' und sein Nachhall im geteilten Deutschland." In: 1917. Revolution: Russland und die Folgen, eds. Deutsches Historisches Museum and Schweizer Nationalmuseum, 125-39. Berlin: Sandstein Verlag, 2017.

- Schnell, Felix. Räume des Schreckens. Gewalträume und Gruppenmilitanz in der Ukraine 1905-1933. Hamburg: Hamburger Edition, 2012.

- Schuster, Frank M. Zwischen allen Fronten. Osteuropäische Juden während des Ersten Weltkrieges (1914-1919). Köln et al.: Böhlau, 2004.

- Stalmann, Volker and Jutta Stehling. Der Hamburger Arbeiter-und Soldatenrat 1918/19. Düsseldorf: Droste, 2013. 


\section{Andreas Schulz}

\section{"KAJ IMA TO OPRAVITI Z NAMI?«- PONOVNO VREDNOTENJE RUSKE REVOLUCIJE V NEMČIJI}

\section{POVZETEK}

Če pogledamo trenutno stanje na področju raziskav, bi lahko dobili vtis, da je bila revolucija tesno povezana z vojno in krizo carske Rusije. V obsežni literaturi o svetovni vojni so poudarjeni naključni dejavniki vojaških dogodkov, hkrati pa se zanemarjajo nekatere družbene sile in strukture politične moči v vojskujočih se družbah. Rdeči oktober se pojavi zgolj kot dejanje drugotnega pomena v veliki drami evropskega bojišča. Veliko je bilo napisanega o »krvavi zemlji « in »poljih smrti< na nekaterih kontaminiranih območjih, kjer je bilo nasilje od začetka 20. stoletja nenehno del vsakdanjega življenja. Kulturalistični liberalni zgodovinarji se pri razlaganju ljudskih vstaj navadno bolj osredotočajo na miselne in kulturne dispozicije, ki se jim zdijo pomembne. Vendar pa pri globalističnem pristopu, v okviru katerega se ne preučujejo specifična razmerja, ki so povzročila revolucije $\mathrm{v}$ Rusiji, Nemčiji, na Madžarskem in drugod, obstaja tveganje, da se te revolucije degradirajo $v$ pojave drugotnega pomena glede na veliko vojno ali zgolj v eno od faz razbesnele državljanske vojne, ki je srce Evrope spremenila v skupinsko klavnico. Avtor namesto tega obravnava različne politične in družbene pogoje, ki so ločevali evropske države med vojno in zaradi katerih so bile te bolj ali manj dovzetne za izzive ruskih revolucij. Razlikovanja in primerjave so potrebne, da bi lahko razumeli, zakaj je »velika socialistična oktobrska revolucija $\ll$ po 100 letih še vedno pomembna. 